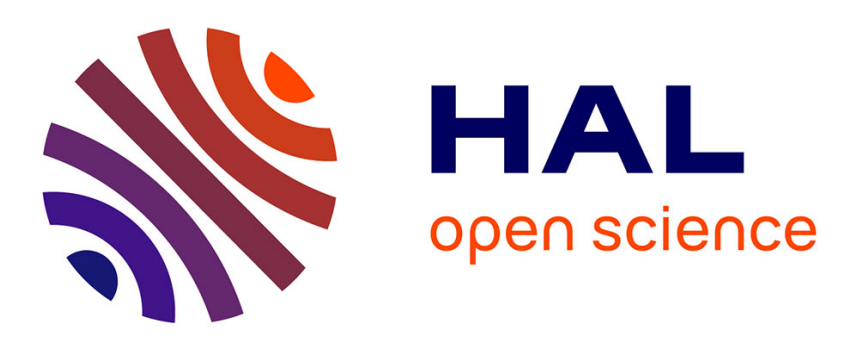

\title{
Powered two wheeler riders' risk of crashes associated with filtering on urban roads
}

\author{
Nicolas Clabaux, Jean-Yves Fournier, Jean Emmanuel Michel
}

\section{To cite this version:}

Nicolas Clabaux, Jean-Yves Fournier, Jean Emmanuel Michel. Powered two wheeler riders' risk of crashes associated with filtering on urban roads. Traffic Injury Prevention, 2017, 18 (2), pp.182-187. 10.1080/15389588.2016.1225298. hal-01403884v2

\section{HAL Id: hal-01403884 \\ https://hal.science/hal-01403884v2}

Submitted on 9 Jan 2018

HAL is a multi-disciplinary open access archive for the deposit and dissemination of scientific research documents, whether they are published or not. The documents may come from teaching and research institutions in France or abroad, or from public or private research centers.
L'archive ouverte pluridisciplinaire HAL, est destinée au dépôt et à la diffusion de documents scientifiques de niveau recherche, publiés ou non, émanant des établissements d'enseignement et de recherche français ou étrangers, des laboratoires publics ou privés. 


\title{
Powered two wheeler riders' risk of crashes associated with filtering on urban roads
}

Nicolas Clabaux*, Jean-Yves Fournier, Jean-Emmanuel Michel

IFSTTAR, TS2-LMA

304 Chemin de la Croix Blanche F-13300 Salon de Provence, France

*Corresponding author: e-mail: nicolas.clabaux@ifsttar.fr

\begin{abstract}
Objective: The objective of this study is to estimate the crash risk per kilometer travelled by powered two wheeler riders filtering through traffic on urban roads.

Methods: Using the traffic injury crashes recorded by the police over a period of three years on fourteen sections of urban roads in the city of Marseille, France and a campaign of observations of powered two-wheelers, the crash risk per kilometer travelled by powered two-wheelers filtering was estimated and compared to the risk of powered two-wheelers that did not filter.

Results: The results show that the risk of powered two-wheeler riders being involved in injury crashes while filtering is significantly higher than the risk for riders who do not filter. For the fourteen sections studied, it is 3.94 times greater (95\% CI: 2.63; 5.89). This excess risk occurred for all powered two-wheeler categories. Furthermore, no space appears to be safer than the others for filtering. Riders filtering forward along the axis of the carriageway, along bus lanes or between traffic lanes (lane-splitting) all have a crash risk greater than the risk of those who do not filter.

Conclusions: All measures limiting the practice of filtering by powered two-wheelers on urban roads would probably contribute to improving the safety of their users.
\end{abstract}

KEYWORDS: Powered two-wheelers; motorcycle; moped; filtering; crash risk; lane splitting

\section{INTRODUCTION}

For the last twenty years, the use of powered two-wheelers (PTW) has risen in large European metropolitan areas (European Commission 2013), although this increase has clearly slowed down since 2008 due to the economic crisis (ACEM 2015). In France, the latest national survey of travel and transportation done in 2008 showed that urban areas with over 100,000 residents with regular automobile traffic congestion are where PTW use has increased (CGDD 2010, p.39). This is in large part due to the ability provided by this form of transport to weave through traffic and to filter between vehicles that are stopped or slowed down. Indeed, this can be seen in the study by Burge et al. (2007), which found that the ability to filter through traffic was a significant factor in motorcycle ownership and commuting. Although the practice of filtering is illegal in most countries around the world, it may, in certain highly congested areas, account for a significant share of trips (Aupetit et al. 2015; Mulvihill et al. 2013). Aupetit et al. (2015), for example, demonstrated that it accounts on average for $72 \%$ of travel time and $77 \%$ of the distances travelled by motorcycle commuters in the Paris region. Yet this practice is considered risky by PTW users, as well as by car drivers (Beanland et al. 2015; Hidalgo et al. 2015; Huth et al. 2014). Crash studies suggest that it does indeed give rise to the production of injury crashes (see, for example: Clarke et al. 2004; Hurt et al. 1981; Maestracci et al. 2012; Rice et al. 2015 Van Elslande et al. 2014). Clarke et al. (2004), for example, demonstrated that one PTW crash out of twenty recorded in Great Britain involved a PTW filtering through traffic. This practice also appears to cause special problems for pedestrians (see Beanland 
et al. 2015). In a previous study, we furthermore showed that in more than half of all crashes involving a PTW and a pedestrian, the PTW was filtering at the time of the crash (see Clabaux et al. 2014). The objective of the study presented in this article is to assess the risk to PTW riders of being involved in an injury crash when they filter through traffic and to compare this risk to that run when they do not filter.

This article is focused on the risk related to filtering on urban roads. A previous study of a different context, urban expressways, revealed that filtering is associated with an excess risk of crashes (approximately 2.5 times greater; see Clabaux et al. 2015). The objective of the present research was to examine whether this is also verifiably on urban roads.

These results should provide us with lessons for countries with relatively low rates of powered two-wheeler use, some of which are starting to legalize this practice, but also for countries with high rates of powered two-wheeler use where the erratic filtering behaviors by powered two-wheelers are not without problems (Haque et al. 2008; Lan and Chang 2015; Vlahogianni 2014).

\section{METHOD}

\section{$\underline{\text { Area studied }}$}

This research was carried out on the territory of the city of Marseille. With over 1.5 million residents, Marseille is one of the France's twelve metropolitan areas. Located on the Mediterranean coast, PTW use has long been quite popular here. Thus there is a particularly high crash rate. Indeed, the city of Marseille is, after Paris, the city that has the largest number of injury crash involving PTWs (some 1,300 crashes recorded by the police each year). Our investigations concerned 14 sections of main urban roads (arterial streets) located in the city center, accounting for $18 \mathrm{~km}$ of roadways. They have certain number of shared characteristics such as the presence of several lanes going in the same direction, intersections that usually have traffic lights, and the presence bus lanes on most of them. These are sections for which we had accurate traffic data due to the presence of electromagnetic loops at regular intervals. These data were gathered in the context of other studies dealing with the effects of bus lanes on safety (see Clabaux et al. 2014; Fournier et al. in press).

\section{Approach adopted}

For each of the 14 sections studied over a period of three years (from 2007 to 2009), the following were estimated:

- The risk for PTW riders of being involved in an injury crash for each kilometer travelled while filtering, and the $95 \%$ confidence interval (CI). (a)

- The risk of crashes for PTW riders when they do not filter and its 95\% CI. (b)

In the second phase, for each section the relative risk (RR) $(a) /(b)$ (and its $95 \%$ confidence interval) for these two populations was estimated using the following formula:

$\mathrm{RR}=\frac{(a)}{(b)}=\frac{\text { (Number of PTW riders involved in crashes while filtering) / (Number of PTW riders x km filtering) }}{\text { (Number of PTW riders involved in crashes while not filtering) / (Number of PTW riders x km not filtering) }}$

Lastly, in the third phase, a relative risk common to all the sections and its 95\% CI was calculated by performing a meta-analysis of data for the 14 sections. Any presence of heterogeneity in the results between the sections studied was examined using the DerSimonian and Laird's $Q$ statistic (Hasselbald and McCrory 1995). This test is used to measure any discordance in the results on one or more sections compared with the common results. A random-effects model and the generic inverse variance method were used to compensate for the heterogeneity of 
studies in terms of environment sections (road layout, traffic conditions, for example). Effect sizes were expressed as weighted mean difference (WMD) and 95\% confidence interval (CI).

It should be noted that the investigations covered weekdays (including saturdays and excluding holidays) and daytime hours (6 am to $10 \mathrm{pm}$ ). In large cities in France, such as Paris or Marseille, powered two-wheeler use is mainly a practical question for commuting on weekdays (see STIF 2013, Institut d'Aménagement d'Urbanisme d'Île-de-France 2009). STIF (2013) for example, showed that, in the center of Paris and in the entire Île-deFrance region, there are nearly 5 times more trips using powered two-wheelers on weekdays. Furthermore, the safety problems raised by filtering practices among powered two-wheelers mainly arise during the week when there is traffic congestion (Clarke et al. 2004). These are the two main reasons that led us to focus on weekdays and daytime hours.

It should also be noted that all these investigations first dealt with all categories of PTW taken together and all filtering practices taken together. In a second phase, they were carried out for the three main administrative categories of PTW (making a distinctions between mopeds, light motorcycles and heavy motorcycles) and for the three main kinds of filtering, i.e. filtering forward along the axis of the carriageway, filtering forward in a bus lane and filtering forward in the space between traffic lanes going in the same direction (lane-splitting). Fig.1 illustrates these different types of filtering maneuvers. These three configurations were studied because they are the three main configurations that give rise to crashes in France (see Clabaux 2006; Maestracci et al. 2012; Van Elslande et al. 2014). According to data analyzed in Clabaux (2006), these three configurations represent $87.5 \%$ of traffic crashes involving PTW filtering. According to another work (see Clabaux et al. 2014), these three configurations represent $67 \%$ of traffics crashes involving a pedestrian and a PTW filtering.

\section{$\underline{\text { Data }}$}

In order to determine the number of PTW riders involved in crashes while filtering (or not), police reports for injury crashes that occurred between 2007 and 2009 on the 14 sections studied were used. They were the most recent available data at the beginning of the work. Each crash case involving at least one PTW gave rise to an indepth analysis to determine whether the PTW was filtering at the time of the crash and, if so, determining what space he/she was using to filter (along the axis of the carriageway, bus lane, space between traffic lanes).

Concerning the number of PTW x kilometers exposed to crash risks when filtering and when not filtering on the sections during the periods in question, for each year studied (2007 to 2009) the first stage consisted in estimating the total amount of PTW traffic on each section during the time periods in question (6 am to $10 \mathrm{pm}$ ). For this, the total hourly traffic data gathered from 2007 to 2009 by the electromagnetic loops installed on the streets studied were used. As PTW are not distinguished from four-wheeled vehicles in these counts, a campaign of observations of PTW traffic was carried out by investigators to estimate what share they account for in the traffic. Fifty-six hours of observations, 28 of which were during peak hours (between 7 am and 9 am or between $4 \mathrm{pm}$ and $7 \mathrm{pm}$ ) and 28 off-peak hours, distributed randomly over the entire year of 2013 and on the 14 sections, were carried out by investigators positioned on the sidewalks. Each observation sequence lasted one hour. During this sequence, the investigator recorded the number of PTWs that drove past him/her and, for each PTW, the administrative category (moped, light motorcycle or heavy motorcycle), whether it was filtering or not and, if so, what space it used to filter.

It should be noted that, during these observations, the investigators did not stay at one fixed point, but rather constantly walked about at a slow pace throughout the section observed. This strategy was adopted due to the 
great volatility of the practice of filtering and in order to report on the practice of filtering for all the sections and not just for one point in particular.

Beyond finding out how many riders had used the sections studied between 2007 and 2009, these observations enabled us to estimate what share of them filtered and what share was not filtering. In order to express risk exposures in vehicles $x$ kilometers, the number of riders observed each time was multiplied by the length of the section they were driving on.

All of these investigations were based on the hypothesis that the share that PTW (and the share of each category of PTW) account for in total traffic did not change between 2007-2009 and 2013. On the national level, according to transport statistics, PTW traffic and the share it accounts for in total road traffic appear to have remained fairly stable since 2007. For example, according to the Commissariat Général au Développement Durable (see CGDD 2014), their share in traffic increased by 1.3\% per year over the 2007-2013 period. Indeed, PTW traffic increased the most between 1997 and 2007. In Paris, the annual observations carried out on a few boulevards in the city center also suggest that PTW traffic has been stable since 2007 (Mairie de Paris 2014). Lastly, as part of another research project (see Clabaux et al. 2014), a campaign of observations of PTW traffic was carried out in 2011 covering 12 of the 14 sections studied here. The comparison of the proportions observed over these two years on these 12 sections shows that PTW traffic remained stable between 2011 and 2013, since the share of PTWs amounted to $16 \%$ in 2013 vs. $15.6 \%$ in 2011. Concerning the share of each category of PTW in total traffic, here again, the comparison of proportions observed in 2011 and 2013 shows that the distribution remained stable.

All of these investigations are also based on another hypothesis: the share of powered two-wheelers filtering (and therefore the share of powered two-wheelers not filtering) did not change between 2007-2009 and 2013 in the sections studied. The only element at our disposal supporting this hypothesis is the absence of any significant change in PTW use of bus lanes between 2011 and 2013. In fact, we had studied the same sections to see what the share of PTW using bus lanes was in 2011 (see Clabaux et al. 2014). A comparison of the results obtained in 2011 with the results of the observations undertaken in 2013 shows that there has not been any significant change in this use between these two periods. Thus, this assumption appears acceptable, in the absence of other evidence.

\section{RESULTS}

\section{$\underline{\text { Results on filtering behaviors }}$}

Concerning risk exposure, the observations carried out on PTW traffic show that PTW on average account for $17.9 \%$ of the traffic on the 14 sections studied. Light motorcycle users are the most numerous. They account for $44.5 \%$ of PTW traffic. Then come heavy motorcycle and moped users, who account for $37.5 \%$ and $18 \%$, respectively. Concerning the practice of filtering, $20.7 \%$ of PTW x kilometers were travelled while filtering during the period. This proportion reaches $25.4 \%$ during peak hours and $17.8 \%$ during off-peak hours. Concerning the space used to filter, the axis of the carriageway is the most commonly used. Indeed, $42.7 \%$ of PTW riders $\mathrm{x}$ kilometers travelled while filtering took place in this space (see table 1). Then come bus lanes (30.8\%) and the space between traffic lanes going in the same direction (12.8\%). Other spaces represent $13.7 \%$ of these riders $\mathrm{x}$ kilometers. 
Article accepted for publication in Traffic Injury Prevention : article accepted 13 Aug 2016

Author version (post-print version)

\section{Results of crashes analysis}

According to police data, 345 PTW riders were involved in injury crashes on the 14 sections studied during the years 2007, 2008 and 2009. The manoeuver performed by the riders at the time of the crash (filtering or not filtering) has been determined for 309 of them. Among these 309 riders involved in crashes, 160 were filtering and 149 were involved in crashes while driving in the general traffic lanes (see Table 2). Among the various categories of PTW, moped riders were proportionally those who had the fewest crashes while filtering: $45 \%$ of them were filtering when the crash occurred. This proportion is $57 \%$ for light motorcycle riders and $54 \%$ for heavy motorcycle riders, respectively.

Concerning the space used when filtering, the axis of the carriageway is most commonly observed in crashes: $40 \%$ of riders filtering forward at the time of the crash were using this space. Then come bus lanes (33\%) and spaces between traffic lanes going in the same direction (10\%) (see Table 3). The remaining cases concerned other, less common, spaces, such as a traffic lane that was free for filtering, sidewalks, etc.

In terms of the processes at work in crashes, among the 160 riders involved in crashes while filtering, 83 had not been previously detected by a car driver in the lane of vehicles being overtaken, when engaging a maneuver for changing lanes, turning right/left (toward another street or access) or making a U-turn.

Another aspect that appears with the analysis of the crash cases concerns the influence of vehicles queues, which often obstruct visibility between the PTW and the vehicle or pedestrian it collides with. The detailed study of police reports shows that among the remaining 77 riders who filtered, 59 were not detected or were detected very late due to the blocked visibility caused by the queue(s) of cars overtaken. 24 of these 59 riders collided with pedestrians.

\section{$\underline{\text { Risks assessment results }}$}

For each section, Table A1 presents the number of PTW riders involved in injury crashes according to whether they were filtering or not, risk exposures, when filtering and when not filtering, expressed in vehicles $\mathrm{x}$ kilometers, the estimation of crash risks and their $95 \%$ confidence interval.

The relative risk is significantly higher for filtering on 10 of the 14 sections studied. It is never significantly lower (see Table A2). The meta-analysis of the results obtained individually on each section gave a common relative risk with heterogeneity of 3.67 (95\% CI $[2.93 ; 4.60]$ ) and a common relative risk corrected for heterogeneity of 3.94 , with a $95 \%$ confidence interval of $[2.63 ; 5.89]$ (Table A2). The same approach was adopted for riders of different categories of PTW. Table 4 presents the relative risks for each PTW category.

Furthermore, the risk of crashes associated with filtering is greater for mopeds ( 2.09 (95\% CI $[1.41 ; 3.10])$ greater than for light motorcycle riders and 2.02 (95\% CI [1.35; 3.03]) greater than for heavy motorcycle riders). There is no significant difference between light motorcycle and heavy motorcycle riders.

Concerning the space used for filtering, no one space appears to be safer than the others - no matter which space is used, the excess crash risk is large. Table 5 presents the relative risks for the three main spaces used by PTW. The relative risk of crash for the other spaces used was not calculated due to the small number of riders involved in traffic crashes. 


\section{DISCUSSION}

The results presented here show that PTW riders filtering on urban roads have a risk of being involved in injury crashes that is nearly four times greater (3.94 times) than for riders driving in general traffic lanes. This result is consistent with that obtained in another study on a different context: urban expressways (see Clabaux et al. 2015). How can this difference in risks be explained? It may firstly be that PTW riders filtering do not have the same risk factors as those who stay in the traffic flow, such as age, experience, driving style or the weight/power ratio of their vehicle. The method adopted did not make it possible to check the influence of these confounding factors. But other elements than those concerning the riders' characteristics are no doubt also at work in this risk difference. This excess risk could firstly be explained by the differential in the positioning on the carriageway between riders filtering and riders driving in their lane. Filtering by PTW riders leads these users to occupy spaces along the carriageway (notably the axis of the carriageway, the space between traffic lanes and bus lanes) where they are no doubt less cognitively conspicuous, that is to say less expected and less sought out by car drivers or pedestrians than when they are driving in the lanes. This differential in their positioning on the carriageway in relation to other vehicles may contribute to it being harder for them to be detected by car drivers, for example when seeking information before undertaking maneuvers for changing lanes, turning right, turning left or making a U-turn. Various authors have suggested this (see for example: Clarke et al. 2004; Crundall et al. 2008 ; Huth et al. 2014; Rogé et al. 2010). This is furthermore what is suggested by the analysis of the crash cases.

Our results also show that there does not appear to be any space (among the three studied) safer than the others for filtering forward along queues of cars. Indeed, there is no significant difference in risks between the three spaces studied. There does appear to be a tendency toward a slightly lower risk for powered two-wheelers filtering forward along the carriageway. This tendency is hard to explain. It may be that it comes from the fact that these riders are less exposed to manoeuvres by the vehicles in the queues that they overtake. Indeed, the sections studied are mostly urban arterials with several lanes of traffic going in the same direction and on which left turns are usually forbidden or a very difficult. Concerning the risks related to using bus lanes, the results that we obtained are consistent with previous studies (see Clabaux et al. 2014, and York et al. 2010). These studies report higher crash risk for powered two-wheelers riding in bus lanes, all types of use combined, for filtering or not. However, the present results suggest that filtering forward in a bus lane is associated with a crash risk higher than traveling in a bus lane (without filtering). Indeed, we found in Clabaux et al. (2014) that the risk for PTW riders who ride in bus lanes (fort filtering or not) of being involved in an injury crash is 3.25 times higher (95\% CI $[2.03 ; 5.21])$ than the risk run by riders who ride in general traffic lanes. Here, we found, that riders who filter forward in a bus lane have a risk 5.60 higher $(95 \%$ CI $[3.21 ; 9.95])$ than riders travelling in general traffic lanes.

The study presented here has a certain number of limitations. Firstly, it is based on strong hypotheses: filtering behaviors and the share of PTW (and each category of PTW) in total traffic did not change between 2007-2009 and 2013. Secondly, we were only interested in the association between filtering forward on vehicle queues, the space used for filtering and involvement in crashes. The possible influence of confounding factors therefore could not be controlled. Furthermore, we did not make any accurate measurement of the conditions under which filtering was performed (traffic conditions, speed of the powered two-wheelers, lanes geometry, etc.), as was 
Article accepted for publication in Traffic Injury Prevention : article accepted 13 Aug 2016

Author version (post-print version)

done by Vlahogianni (2014) on one site. This might have enabled us to propose stronger interpretations of the excess risks observed.

The work that we have presented here needs to be consolidated, notably by considering a larger number and a wider variety of sections. Furthermore, it is based on a relatively small number of observations of risk exposure. From this point of view, the use of data collected from video recordings could be useful in the future.

Nonetheless, these results suggest that all measures that help to discourage the practice of filtering by PTW on urban roads would no doubt contribute to improving safety. This could involve the layout of urban roads, for example. Indeed, a study of crash sites suggests that reducing the width of traffic lanes to a strict minimum could be an interesting proposal. Two studies with different approaches suggest a decisive influence of lane width in the decision by powered two-wheeler users to filter forward on vehicle queues (see Haque and Hoong Chin 2010; Vlahogianni 2014). Combining lane width reduction with placing medians or pedestrian islands, notably at junctions and pedestrian crossings, and better control of bus lanes use, could probably contribute to achieving this objective. Assessment studies, notably of the before-and-after type, of the effects of these measures on this type of crash are still needed. Without going so far as the construction of dedicated powered two-wheelers lane, as experimented in Malaysia (Radin Umar et al. 1995), and which would be hard to insert into European cities, another prospect could consist in reserving lanes to powered two-wheelers. Strong assessment studies would nonetheless be needed insofar as the knowledge current available in the literature rather tends to demonstrate that this would have a harmful effect on safety (see Clabaux et al. 2014, and York et al. 2010, concerning the effect of powered two-wheelers' use of bus lanes). Lastly, in terms of the expected effects of the possible legalization of filtering behaviors, which is being explored in some countries, our results suggest that this would probably have a negative effect on safety.

\section{Acknowledgements}

We would like to thank Mr. Marc Jouvenne and Mr. Franck Lavergne of the Marseille Provence Métropole Urban Community's Direction Gestion des Equipements de Trafic (Traffic Equipment Management Division) for the large amounts of traffic data that they agreed to supply us with.

\section{References}

ACEM. The motorcycle industry in Europe. Industry Report 2015. Brussels, Belgium: ACEM publications; 2015.

Aupetit S, Espié S, Bouaziz S. Naturalistic study of riders' behaviour in lane-splitting situations. Cogn Tech Work. 2015; 17:301-313.

Beanland V, Pammer K, Sledziowska M, Stone A. Drivers' attitudes and knowledge regarding motorcycle lane filtering practices. In: Proceedings of the first Australasian Road Safety Conference, Gold Coast, Australia, October 14-16, 2015; 1-11.

Burge P, Fox J, Kouwenhoven M, Rohr C, Wigan MR. Modeling of Motorcycle Ownership and Commuter Usage: A UK Study. Transp Res Rec. 2007; 2031: 59-68.

Clabaux N. Prototypical accident scenarios involving powered two-wheelers in urban areas in France and prospects for countermeasures. Adv. Transp. Stud. 2006; A9: 17-28.

Clabaux N, Fournier JY, Michel JE. Powered two-wheeler drivers' crash risk associated with the use of bus lanes. Accid. Anal Prev. 2014; 71: 306-310.

Clabaux N, Fournier JY, Michel JE. Powered two-wheeler drivers' risk of hitting a pedestrian in towns. J Safety Res. 2014; 51:1-5.

Clabaux N, Fournier J.Y, Michel J.E, Huillet, J, Gemy, F, Guéritat, F. Risque d'accident des usagers de deuxroues motorisés associé aux pratiques de remontée de files sur autoroutes urbaines. Rech Transp Secur. 2015; $33: 1-13$.

Clarke DD, Ward PJ, Bartle C, Truman W. In-depth study of motorcycle accidents. London, UK: University of Nottingham, Department for Transport; 2004. Research Report 54. 
Crundall D, Bibby P, Clarke D, Ward P, Bartle C. Car drivers' attitudes towards motorcyclists : a survey. Accid. Anal Prev. 2008; 40: 983-993.

C.G.D.D. (Commissariat Général au Développement Durable). Les comptes des Transports en 2013. 51ème rapport à la commission des comptes des transports de la nation. Tome 1. Paris, France : Ministère de l'Ecologie, de l’Energie, du Développement Durable et de la Mer; 2014.

C.G.D.D. (Commissariat Général au Développement Durable). La mobilité des Français. Panorama issu de l'enquête nationale transports et déplacements 2008. In La Revue du Service de l'Observation et des Statistiques (SOeS) du Commissariat Général au développement durable. Paris, France: Ministère de l'Ecologie, de l'Energie, du Développement Durable et de la Mer; 2010.

European Commission. Making roads safer for motorcycles and mopeds. 2013 Available at: http://ec.europa.eu/transport/road_safety/users/motorcyclists-mopdeds/index_en.htm Accessed December 1, 2015.

Fournier JY, Clabaux N, Brenac T. Sécurité des piétons dans les rues équipées de couloirs réservés aux bus. Rech Transp Secur. In press.

Haque MM, Hoong Chin H, Huang HL. Examining exposure of motorcycles at signalized intersections. Transp Res Rec. 2008; 2048: 60-65.

Haque MM, Hoong Chin H. Right-Angle Crash Vulnerability of Motorcycles at Signalized Intersections. Mixed Logit Analysis. Transp Res Rec. 2010; 2194: 82-90.

Hasselbald V, McCrory DC. Meta-analytic tools for medical decision-making: a practical guide. Medical Decision-making. 1995; 15(1): 81-96.

Hidalgo M, Ragot-Court I, Eyssartier C. La circulation inter-files : pratique pour les deux-roues, mais qu'en pensent les automobilistes? Analyse comparée de discours d'automobilistes sur ce comportement typique des usagers en deux-roues motorisé. Nouvelles perspectives en sciences sociales. $2015 ; 11(1)$ : 253-284.

Hurt HH, Ouellet JV, Thom, DR. Motorcycle accident cause factors and identification of countermeasures. Washington, DC: National Highway Traffic Safety Administration; US Department of Transportation; 1981. DOT-HS-5-01160.

Huth V, Füsslb E, Risserb R. Motorcycle riders' perceptions, attitudes and strategies: Findings from a focus group study. Transp Res Part F: Traffic Psychol Behav. 2014; 25: 74-85.

Institut d'Aménagement et d'Urbanisme d'Île-de-France. Sécurité routière et usage des deux-roues motorisés en Île-de-France. Institut d'Aménagement et d'Urbanisme d'Île-de-France, June 2009, 54p.

Lan CL, Chang GL. Empirical study of scooter-vehicle mixed traffic propagation on urban arterials. Transp Res Rec. 2015; 2491: 32-42.

Maestracci M, Prochasson F, Geffroy A, Peccoud F. PTWs road accidents and their risk perception in dense urban areas; Case of Paris. Accid. Anal Prev. 2012; 49: 114-123.

Mairie de Paris. Les déplacements en deux-roues motorisés. 2014. Available at http://www.paris.fr/viewmultimediadocument?multimediadocument-id=151557 Accessed December 1, 2015.

Mulvihill CM, Salmon PM, Filtness A, Lenné M, Walker GH, Cornelissen M, Young KL. Lane filtering and situation awareness in motorcyclists: an on-road proof of concept study. Proceedings of the Australasian Road Safety Research Policing Education Conference, Brisbane, Queensland, Australia, August 28-30, 2013; 1-12.

Radin Umar RS, Mackay GM, Hills BL. Preliminary analysis of exclusive motorcycle lanes along the federal highway F02, Shah Alam, Malaysia. Journal of IATSS Research. 1995; 19(2): 93-98.

Rice T, Troszak L, Erhardt T. Motorcycle lane-splitting and safety in California. Berkeley: University of California; Safe Transportation Research \& Education Center; 2015.

Rogé J, Ferretti J, Devreux G. Sensory conspicuity of powered two-wheelers during filtering manoeuvres, according the age of the car driver. Le Travail Humain. 2010, 73(1):7-30.

STIF. Enquête globale transport. La mobilité en Île de France. Les déplacements du week end. Syndicat des transports d'Île-de-France. Direction régionale et interdépartementale de l'équipement et de l'aménagement d'Îlede-France. Observatoire de la mobilité en Île-de-France, 2013.

Van Elslande P, Fournier JY, Parraud C. Accidentalité des deux-roues motorisés à usage urbain. Rapport sur Convention Dscr / Ifsttar n ${ }^{\circ}$ 2200666500, 2014.

Vlahogianni EI. Powered-Two-Wheelers kinematic characteristics and interactions during filtering and overtaking in urban arterials. Transp Res Part F: Traffic Psychol Behav. 2014, 24: 133-145.

York I, Ball S, Anjum O, Webster D. Assessment of TfL's experimental scheme to allow motorcycles onto withflow bus lanes on the TRLN., Crowthorne, UK: Transport Research Laboratory; 2010. Final Project Report PPR 495. 
Fig.1 Photographs illustrating the different types of filtering manoeuvers studied

a) filtering forward along the axis of the carriageway; b) filtering forward in a bus lane; c) filtering forward in the space between traffic lanes going in the same direction (lane-splitting)

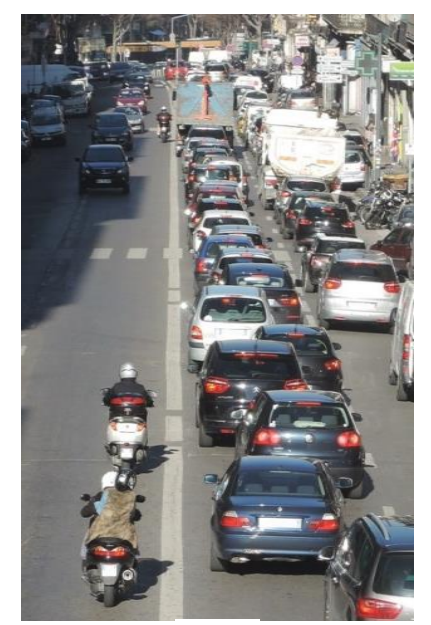

a)

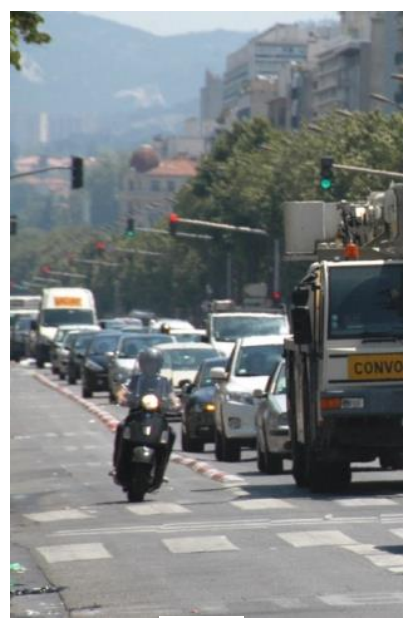

b)

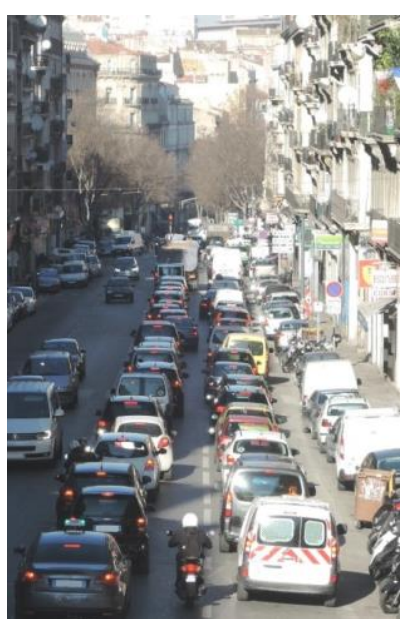

c) 
Table 1. Risk exposure: estimation of riders x kilometers filtering and not filtering. Years $2007-2009$, on all 14 sections studied and on weekdays between 6 am and $10 \mathrm{pm}$.

\begin{tabular}{|c|c|c|c|c|c|c|}
\hline & $\begin{array}{l}\text { PTWs x kms } \\
\text { travelled } \\
\text { while filtering } \\
\text { (thousands) }\end{array}$ & $\begin{array}{l}\text { of which: } \\
\text { Along the } \\
\text { axis of the } \\
\text { carriageway } \\
\text { (thousands) }\end{array}$ & $\begin{array}{c}\text { In the bus } \\
\text { lane } \\
\text { (thousands) }\end{array}$ & $\begin{array}{c}\text { Between } \\
\text { lanes going } \\
\text { in the same } \\
\text { direction } \\
\text { (thousands) }\end{array}$ & $\begin{array}{c}\text { Other } \\
\text { spaces } \\
\text { (thousands) }\end{array}$ & $\begin{array}{l}\text { PTWs x kms } \\
\text { travelled } \\
\text { while not } \\
\text { filtering } \\
\text { (thousands) }\end{array}$ \\
\hline Moped riders & $1378(20.8 \%)$ & $482(35.1 \%)$ & $\begin{array}{c}539 \\
(39.1 \%) \\
\end{array}$ & $\begin{array}{c}171 \\
(12.4 \%) \\
\end{array}$ & $\begin{array}{c}185 \\
(13.4 \%) \\
\end{array}$ & $\begin{array}{c}5248 \\
(79.2 \%) \\
\end{array}$ \\
\hline $\begin{array}{l}\text { Light motorcycle } \\
\text { riders }\end{array}$ & $3377(20.4 \%)$ & $\begin{array}{c}1442 \\
(42.7 \%)\end{array}$ & $\begin{array}{c}1047 \\
(31 \%)\end{array}$ & $\begin{array}{c}409 \\
(12.1 \%) \\
\end{array}$ & $\begin{array}{c}478 \\
(14.2 \%) \\
\end{array}$ & $\begin{array}{c}13171 \\
(79.6 \%)\end{array}$ \\
\hline $\begin{array}{l}\text { Heavy motorcycle } \\
\text { riders }\end{array}$ & $2938(21.1 \%)$ & $1447(40 \%)$ & $762(26 \%)$ & $\begin{array}{c}363 \\
(12.4 \%) \\
\end{array}$ & $\begin{array}{c}364 \\
(12.4 \%) \\
\end{array}$ & $\begin{array}{c}10986 \\
(78.9 \%) \\
\end{array}$ \\
\hline All PTW riders & $7822(20.7 \%)$ & $\begin{array}{c}3336 \\
(42.7 \%)\end{array}$ & $\begin{array}{c}2408 \\
(30.8 \%)\end{array}$ & $\begin{array}{c}1002 \\
(12.8 \%)\end{array}$ & $\begin{array}{c}1075 \\
(13.7 \%)\end{array}$ & $\begin{array}{c}29959 \\
(79.3 \%)\end{array}$ \\
\hline
\end{tabular}

Table 2. Numbers of riders involved in injury crashes in 2007, 2008 and 2009 on the 14 sections studied and during the periods covered, according to whether they were filtering or not.

\begin{tabular}{lccc}
\hline & $\begin{array}{c}\text { Number of riders involved } \\
\text { in injury crashes }-14 \\
\text { sections }-6 \text { am to } 10 \mathrm{pm}\end{array}$ & $\begin{array}{c}\text { Filtering at the time } \\
\text { of the crash }\end{array}$ & $\begin{array}{c}\text { Not filtering at the } \\
\text { time of the crash }\end{array}$ \\
\hline Moped riders & 108 & $49(45 \%)$ & $59(55 \%)$ \\
\hline Light motorcycle riders & 104 & $59(57 \%)$ & $45(43 \%)$ \\
\hline Heavy motorcycle riders & 96 & $52(54 \%)$ & $44(46 \%)$ \\
\hline All PTW riders & $309 *$ & $160(52 \%)$ & $149(48 \%)$ \\
\hline
\end{tabular}

*Among the 309 PTW involved in injury crashes, we were unable to identify the administrative category of the vehicle (between mopeds, light motorcycles and heavy motorcycles) in one case.

Table 3. Spaces used by PTW riders filtering at the time of the crash. Years $2007-2009$, on the 14 sections studied and on weekdays from 6 am to $10 \mathrm{pm}$.

\begin{tabular}{|c|c|c|c|c|c|}
\hline & \multirow[b]{2}{*}{$\begin{array}{l}\text { Number of riders } \\
\text { filtering at the time of } \\
\text { the crash }-14 \text { sections } \\
-6 \text { am to } 10 \mathrm{pm}\end{array}$} & \multicolumn{4}{|c|}{ of which } \\
\hline & & $\begin{array}{l}\text { Along the } \\
\text { axis of the } \\
\text { carriageway }\end{array}$ & $\begin{array}{l}\text { In the } \\
\text { bus lane }\end{array}$ & $\begin{array}{c}\text { Between } \\
\text { traffic } \\
\text { lanes going } \\
\text { in the same } \\
\text { direction }\end{array}$ & $\begin{array}{l}\text { Other } \\
\text { spaces }\end{array}$ \\
\hline Moped riders & 49 & $19(39 \%)$ & $15(31 \%)$ & $9(18 \%)$ & $6(12 \%)$ \\
\hline Light motorcycle riders & 59 & $24(41 \%)$ & $20(34 \%)$ & $3(5 \%)$ & $12(20 \%)$ \\
\hline Heavy motorcycle riders & 52 & $21(40 \%)$ & $17(33 \%)$ & $4(8 \%)$ & $10(19 \%)$ \\
\hline All PTW riders & 160 & $64(40 \%)$ & $52(33 \%)$ & $16(10 \%)$ & $28(17 \%)$ \\
\hline \multicolumn{6}{|c|}{$\begin{array}{l}\text { Table 4. Estimation of the relative risks and } 95 \% \text { CI for the different PTW categories, on all } 14 \text { sections studied } \\
\text { and for the } 2007-2009 \text { period (weekdays, } 6 \mathrm{am}-10 \mathrm{pm} \text { ). }\end{array}$} \\
\hline & \multicolumn{2}{|l|}{$\mathrm{RR}$} & \multicolumn{3}{|c|}{$95 \% \mathrm{CI}$} \\
\hline Moped riders & \multicolumn{2}{|l|}{3,30} & 2,56 & \multicolumn{2}{|r|}{7,96} \\
\hline Light motorcycle riders & \multicolumn{2}{|l|}{3,86} & 2,55 & \multicolumn{2}{|r|}{5,84} \\
\hline Heavy motorcycle riders & \multicolumn{2}{|l|}{3,65} & 2,14 & \multicolumn{2}{|r|}{5,52} \\
\hline PTW riders & \multicolumn{2}{|l|}{3,94} & 2,63 & \multicolumn{2}{|r|}{5,89} \\
\hline
\end{tabular}


Article accepted for publication in Traffic Injury Prevention : article accepted 13 Aug 2016 Author version (post-print version)

Table 5. Estimation of the relative risks and 95\% CI for the different spaces used by PTW for filtering, on all 14 sections studied and for the 2007-2009 period (weekdays, $6 \mathrm{am}-10 \mathrm{pm}$ ).

\begin{tabular}{lccc}
\hline & RR & \multicolumn{3}{c}{$95 \%$ CI } \\
\hline Axis of the carriageway & 3,85 & 2,24 & 6,61 \\
\hline Bus lanes & 5,60 & 3,21 & 9,95 \\
\hline Between car lanes & 5,31 & 2,30 & 12,21 \\
\hline
\end{tabular}

\section{Appendices}

Table A1. Number of riders involved in crashes when filtering and when not filtering, estimation of the number of kilometers travelled by the powered two-wheeler riders when filtering and when not filtering, estimation of the crash risks and $95 \%$ CI, for each section studied for the 2007-2009 period.

\begin{tabular}{|c|c|c|c|c|c|c|}
\hline Sections & $\begin{array}{l}\text { No of PTW } \\
\text { involved in } \\
\text { crashes while } \\
\text { filtering }\end{array}$ & $\begin{array}{l}\text { PTWs x kms } \\
\text { travelled while } \\
\text { filtering } \\
\text { (thousands) }\end{array}$ & $\begin{array}{c}\text { Crash per } 1000 \\
\text { kilometers } \\
\text { travelled (and } \\
95 \% \mathrm{CI} \text { ) }\end{array}$ & $\begin{array}{c}\text { No of PTW } \\
\text { involved in } \\
\text { crashes while } \\
\text { not filtering }\end{array}$ & $\begin{array}{l}\text { PTWs x kms } \\
\text { travelled while } \\
\text { not filtering } \\
\text { (thousands) }\end{array}$ & $\begin{array}{c}\text { Crash per } 1000 \\
\text { kilometers } \\
\text { travelled (and } \\
95 \% \mathrm{CI} \text { ) }\end{array}$ \\
\hline $\begin{array}{l}\text { Bd. Schlœsing } \\
\text { (toward Rabatau) }\end{array}$ & 6 & 544 & $\begin{array}{c}0.011 \\
{[0.002 ; 0.02]} \\
\end{array}$ & 7 & 1869 & $\begin{array}{c}0.004 \\
{[0.001 ; 0.007]} \\
\end{array}$ \\
\hline $\begin{array}{l}\text { Bd. Baille (toward } \\
\text { Castellane) }\end{array}$ & 23 & 850 & $\begin{array}{c}0.027 \\
{[0,016 ; 0,038]}\end{array}$ & 17 & 1917 & $\begin{array}{c}0.009 \\
{[0.005 ; 0.013]}\end{array}$ \\
\hline $\begin{array}{l}\text { Bd. Duparc (toward } \\
\text { Timone) }\end{array}$ & 14 & 1428 & $\begin{array}{c}0.010 \\
{[0.005 ; 0.015]}\end{array}$ & 7 & 629 & $\begin{array}{c}0.011 \\
{[0.003 ; 0.019]} \\
\end{array}$ \\
\hline $\begin{array}{l}\text { Bd. Michelet (toward } \\
\text { Mazargues) }\end{array}$ & 8 & 621 & $\begin{array}{c}0.013 \\
{[0.004 ; 0.022]}\end{array}$ & 6 & 6377 & $\begin{array}{c}0.001 \\
{[0.0002 ; 0.002]}\end{array}$ \\
\hline $\begin{array}{l}\text { Bd. Michelet (toward } \\
\text { Prado) }\end{array}$ & 14 & 710 & $\begin{array}{c}0.020 \\
{[0.009 ; 0.03]}\end{array}$ & 15 & 4362 & $\begin{array}{c}0.003 \\
{[0.002 ; 0.005]} \\
\end{array}$ \\
\hline $\begin{array}{l}\text { Bd. Corderie (toward } \\
\text { Corse) }\end{array}$ & 9 & 111 & $\begin{array}{c}0.081 \\
{[0.03 ; 0.132]}\end{array}$ & 8 & 489 & $\begin{array}{c}0.016 \\
{[0.005 ; 0.028]}\end{array}$ \\
\hline $\begin{array}{l}\text { Bd. Corderie (toward } \\
\text { the square) }\end{array}$ & 4 & 191 & $\begin{array}{c}0.021 \\
{[0.001 ; 0.041]} \\
\end{array}$ & 4 & 504 & $\begin{array}{c}0.008 \\
{[0.0002 ; 0.016]}\end{array}$ \\
\hline $\begin{array}{l}\text { Av. Mazargues } \\
\text { (toward Prado 2) }\end{array}$ & 8 & 226 & $\begin{array}{c}0.035 \\
{[0.011 ; 0.059]}\end{array}$ & 4 & 516 & $\begin{array}{c}0.008 \\
{[0.0002 ; 0.015]}\end{array}$ \\
\hline $\begin{array}{l}\text { Bd. Prado 1 (toward } \\
\text { Castellane) }\end{array}$ & 13 & 782 & $\begin{array}{c}0.017 \\
{[0.008 ; 0.026]}\end{array}$ & 11 & 2680 & $\begin{array}{c}0.004 \\
{[0.002 ; 0.007]}\end{array}$ \\
\hline $\begin{array}{l}\text { Bd. Prado } 1 \text { (toward } \\
\text { Michelet) }\end{array}$ & 12 & 596 & $\begin{array}{c}0.020 \\
{[0.009 ; 0.031]}\end{array}$ & 18 & 2881 & $\begin{array}{c}0.006 \\
{[0.003 ; 0.009]}\end{array}$ \\
\hline $\begin{array}{l}\text { Bd. Prado } 2 \text { (toward } \\
\text { David) }\end{array}$ & 11 & 211 & $\begin{array}{c}0.052 \\
{[0.022 ; 0.082]}\end{array}$ & 9 & 2303 & $\begin{array}{c}0.004 \\
{[0.001 ; 0.006]}\end{array}$ \\
\hline $\begin{array}{l}\text { Bd. Prado } 2 \text { (toward } \\
\text { Michelet) }\end{array}$ & 8 & 199 & $\begin{array}{c}0.040 \\
{[0.013 ; 0.067]}\end{array}$ & 7 & 2292 & $\begin{array}{c}0.003 \\
{[0.001 ; 0.005]} \\
\end{array}$ \\
\hline $\begin{array}{l}\text { Crs Lieutaud (toward } \\
\text { Canebière) }\end{array}$ & 14 & 725 & $\begin{array}{c}0.019 \\
{[0.009 ; 0.029]}\end{array}$ & 17 & 1665 & $\begin{array}{c}0.010 \\
{[0.005 ; 0.015]}\end{array}$ \\
\hline $\begin{array}{l}\text { Crs Lieutaud (toward } \\
\text { Baille) }\end{array}$ & 16 & 622 & $\begin{array}{c}0.026 \\
{[0.013 ; 0.038]}\end{array}$ & 19 & 1469 & $\begin{array}{c}0.013 \\
{[0.007 ; 0.019]}\end{array}$ \\
\hline
\end{tabular}

Table A2. Relative crash risks of riders filtering relative to riders not filtering and $95 \%$ confidence intervals for each section studied for the 2007-2009 period.

\begin{tabular}{lccc}
\hline Sections & RR & \multicolumn{2}{c}{$95 \%$ CI } \\
\hline $\begin{array}{l}\text { Bd. Schlœsing } \\
\text { (toward Rabatau) }\end{array}$ & 2.94 & 0.99 & 8.76 \\
\hline $\begin{array}{l}\text { Bd. Baille (toward } \\
\text { Castellane) }\end{array}$ & 3.05 & 1.63 & 5.71 \\
\hline $\begin{array}{l}\text { Bd. Duparc (toward } \\
\text { Timone) }\end{array}$ & 0.88 & 0.36 & 2.18 \\
\hline
\end{tabular}


Article accepted for publication in Traffic Injury Prevention : article accepted 13 Aug 2016 Author version (post-print version)

\begin{tabular}{lccc}
\hline $\begin{array}{l}\text { Bd. Michelet } \\
\text { (toward Mazargues) }\end{array}$ & 13.67 & 4.74 & 39.41 \\
\hline $\begin{array}{l}\text { Bd. Michelet } \\
\text { (toward Prado) }\end{array}$ & 5.73 & 2.77 & 11.88 \\
\hline $\begin{array}{l}\text { Bd. Corderie } \\
\text { (toward Corse) }\end{array}$ & 4.92 & 1.90 & 12.75 \\
\hline $\begin{array}{l}\text { Bd. Corderie } \\
\text { (toward the square) }\end{array}$ & 2.63 & 0.66 & 10.51 \\
\hline $\begin{array}{l}\text { Av. Mazargues } \\
\text { (toward Prado 2) }\end{array}$ & 4.55 & 1.37 & 15.12 \\
\hline $\begin{array}{l}\text { Bd. Prado 1 } \\
\text { (toward Castellane) }\end{array}$ & 4.05 & 1.81 & 9.04 \\
\hline $\begin{array}{l}\text { Bd. Prado 1 } \\
\text { (toward Michelet) }\end{array}$ & 3.22 & 1.55 & 6.68 \\
\hline $\begin{array}{l}\text { Bd. Prado 2 } \\
\text { (toward David) }\end{array}$ & 13.33 & 5.52 & 32.16 \\
\hline $\begin{array}{l}\text { Bd. Prado 2 } \\
\text { (toward Michelet) }\end{array}$ & 13.15 & 4.77 & 36.27 \\
\hline $\begin{array}{l}\text { Crs Lieutaud } \\
\text { (toward Canebière) }\end{array}$ & 1.89 & 0.93 & 3.84 \\
\hline $\begin{array}{l}\text { Crs Lieutaud } \\
\text { (toward Baille) }\end{array}$ & 1.99 & 1.02 & 3.87 \\
\hline \begin{tabular}{l} 
All sections \\
\hline
\end{tabular} & 3.94 & 2.63 & 5.89 \\
\hline
\end{tabular}

